\title{
RACISM AND STEREOTYPE IN GET OUT MOVIE SCRIPT
}

\author{
Deni Sepna Nurhadi \\ Hasbi Assidiqi \\ State Islamic University Sunan Gunung Djati Bandung
}

\begin{abstract}
Racism is a belief or ideology that all members of each racial groups possess characteristics or abilities specific to that race, especially to distinguish it as being either superior or inferior to another racial group. Continuation of a racism is stereotype. Stereotypes are generalized because one assumes that the stereotype is true for each individual person in the category. Literary works applying this concept in many worked and one of them is film. Therefore, the writer is interested in discussing the mentioned topic with objective of the research: To identify how racism constructed in Get Out movie and to analyze the stereotype of racism appeared in Get Out movie. The method used in this research is sociology of literature, because it is appropriate to analyze literary work which focused on the racism attitude in Get Out movie script. The grand theory for the topic is Racism a Short History by George M. Fredrickson and Stereotype as Explanations by Craig McGarty. While the object of this research is Get Out movie script by Jordan Peele. The result of data analysis show that racism constructed by three elements there are dialog, characterization and plot. And stereotype of racism that appeared in Get Out movie is discrimination, prejudice and violence. From the finding of data analysis, it can be concluded that the result of the research is that Get Out movie have a racism content with suitable features that match with the theory. Therefore, it is clear and not surprising if the work indeed has the impression of "racist", since most of literary work with racism issue does have that kind of impression to the readers or the spectators.
\end{abstract}

Keywords: racism, sociology of literature, movie script

\section{Introduction}

Racism, racial discrimination, prejudice and all the intolerance attitude that still living in parts of the world which is stereotypes linked to it as does America. Racism born because of differences in humans. Fredrickson (2002:4) said, "no better example can be found of how a 'cultural essentialism' based on nationality can do the work of racism based squarely on skin color or other physical characteristics". The different of human will give rise stereotype from one group to another group that looks different. In a life, human will definitely be in a group and prejudice will becomes unavoidable when looking at a different group. McGarty (2002:3) states that, "We cannot have an impression of a group unless we can tell the difference between that group and some other group. Categorization is the cognitive process by which we detect those differences and similarities". Literature as its existence to be a reflection of the life can contain the whole aspect that we can find in the real life.

Racism as a problem of social much of which is poured in literary work. Eagleton (1996:2) said that, "Literature is the human work that uses language as a means of outpouring both spoken and written that can cause a sense of beauty as 
well trilling the reader's soul. Perhaps literature is definable not according to whether it is fictional or 'imaginative', but because it uses language in peculiar ways." In essence literary work are divided into three types that is prose, poetry, and drama. The film is now considered as a literary genre since it belongs to the inquiry field of literary studies. According to Klarer (1998:14) "the terms plot, character, setting, narrative perspective, and theme emerge not only in the definitions and characterizations of the genre of the novel but also function as the most important areas of inquiry in film." See the film as a literary genre which has similarities like a drama consist of performance and textual form.

In seeing at something that is going on in a literary work, of course, we have to understand the work in depth, including about the story, characters, and the tragedy that happened in the story. In the story of Get Out movie, all the characteristics which contrast and show only two skin color that is black and white who play an important role in running the story. We are required to understand their position and status in the story to show the many racist issues that contained in this film. The researcher will focus to movie script of this film and use the dialogue from the character to analyze the racist issues that exist in this film with racism theory from Fredrickson and stereotype theory from Craig McGarty.

According to Bordwell (2017) "a narrative is a chain of events linked by cause and effect and occurring in time and space." Get Out movie as a narrative film who telling a black man named Chris Washington who has a white girlfriend Rose Armitage who visited the woman parent's home. Strangeness began to emerge until finally, Chris knew what was going on in that house. In the Get Out movie, the author gives a different dimension of racism. Racist is not just about white people oppressing black people, the author inserted racist finely. Raised something that more contemporary, such as dialogue or words that seem reasonable, but actually make the blacks uncomfortable when it delivered. To found racist issues in Get Out movie the writer will use objective approach to know all the elements of the story such as plot, character, setting, narrative perspective, and theme.

Film as one of the literary modern genres make the researcher interested to study about the film and in particular, we can develop our knowledge and science. After watching and studying Get Out movie, the writer can give some information about racist in this film concerning with the film through the intrinsic element from this story.

Based on the background above, the problems are formulated as follows:

1. How is racism constructed in Get Out movie?

2. What stereotype of racism appeared in Get Out movie?

Based on the statement of the problems above, the objectives are expected as follows:

1. To identify how racism constructed in Get Out movie.

2. To analyze the stereotype of racism appeared in Get Out movie.

\section{Discussions}

Get out movie is a film that write and direct by Jordan Peele in 2017. Get Out movie as a narrative film who telling a black man named Chris Washington as a 
male main character who has a white girlfriend Rose Armitage who visited the woman parent's home. Then the strangeness began to be felt. Many racism issue and stereotype appear in this film.

\section{Racism Constructed in Get Out Movie}

The data is analyse to answer the first statement of problems, named: How is racism constructed in Get Out movie? There are three aspect there is dialog, characterization and plot.

\section{Dialog}

In Get Out movie script there are many dialogue with racism issue

Come on, I get it. White family, black servants. It's a total cliché."

In the dialogue delivered by Dean Armitage to Chris Washington, it was emphasized that the white family with black maids who used to be in the era of slavery were still present today. The second is the suppression of the cliché word which seems to assume that slavery is normal. Unfortunately, Dean said to Chris who was actually a black man. The racism shown by dean Armitage really shows racism against Chris as black Americans. The statement was addressed when Chris saw the maid and gardener in the house as black as himself. When Dean Armitage spoke that this was a cliché thing, as if showing that blacks were indeed intended to be a maid or gardener or could be said to be white slaves. George M. Fredrickson in his book Racism: a short History (2005) stated that racism is not kind of attitude or belief in society. Racism is all about practice, institutions and structure based on strict differentiation. It also can create kind of social order of society, not only theory about human's differentiation. The practice of racism may be done by every person, whatever individually or in a group.

\section{Characterization}

\section{Chris Washington}

The black photographer and the main protagonist of the movie

Chris is the protagonist of the film, a young black man who is easy to get along with and seems to be well-liked. Chris is a talented photographer, whose work Jim Hudson describes as "brutal" and "melancholic." Chris lost his mother at a young age and still feels guilty about not doing more to save her in her final moments. He carries a heavy psychic burden, but bears it with patience and reserve. Chris goes into the weekend with Rose's family cautiously, wary of how he will be treated by a white family, and keeps his cool even when his suspicions are proven correct. In many ways, Chris is martyr-like, enduring the injustices of being a young black man with a resigned determination to survive however he can, until his suspicions are pushed to their limit.

Although in this movie Chris becomes a victim of racism by Armitage family and friend but, Chris did something racist to in this case to white people. Chris is worried that Rose hasn't told her parents that he is black, and fears that they 
won't approve of it. He eventually learns that she's dated numerous black people before him. We can see in the dialog below.

"Do they know I'm black?"

"You know, I don't want to get chased off the lawn with a shotgun."

we can see how Chris view of white people in this case is Armitage family. The term "racism" is often used in a loose and unreflective way to describe the hostile or negative feelings of one ethnic group or "people" toward another and the actions resulting from such attitudes (Fredrickson, 2002).

\section{Plot}

Get out Movie script have 99 pages. Here the researcher will breakdown the script to find plot that build the racism in this movie.

Page 1-3

Andre is a young black man walking alone at night, lost in an affluent white neighborhood. He's kidnapped. This Andre is the same one we meet later in the film (and on page 49 of the script), though his manner and appearance are different, and his name changed to Logan.

As we know in the past of slavery, black abductions often occur.

Page 10-13

Their flirtation is suddenly interrupted when Rose's car hits a deer. It doesn't die immediately and Chris appears more hurt than Rose. An officer arrives and asks Rose for her driver's license. She complies. He then asks Chris for his. Rose objects strenuously, since he wasn't driving. Chris appreciates the support. There are two police in the script but only one in the film.

A racist act was carried out by a police officer against Chris. He ask for the identity of Chris when Chris not driving a car. It can be seen that the police did not believe to Chris because Chris is black people.

\section{Stereotype of Racism That Appeared in Get Out Movie}

\section{discrimination}

Chris Washington as black people often get the experience several forms of discrimination. Discrimination is negative treatment toward inferior races which is given irrationally and causes a harm full impact for them. Through this narrative, Chris Washington as a black people shows us the form of discrimination toward him in his time when he visits a white family house.

One of the discriminations toward colored people is done through a compulsion to admit the falsehood that is created by white people. The human right of free colored people is often seized by white people. The evidence of this condition may be seen as follow: 
"You have been chosen because of the physical advantages you've enjoyed your entire lifetime. With your natural gifts and our determination, we could both be part of something greater. Something perfect."

In the dialogue, there is a scene where Chris Washington is confined in the basement with his legs and arms tied to a chair. In front of him, there is a television that shows a video where there is a grandfather the name is Roman Armitage who speaks like in the dialogue. He said that Chris had been chosen to be a victim of the Armitage family's research. The Armitage family made a study which combined the bodies of black people who were still healthy with the minds of old white people. If we look at the era of slavery in the 19th century that occurred in America, black people were made slaves because they had high and strong postures in spelling out various kinds of work but were considered to lack good thinking. In this scene, it is as if re-showing slavery but with a bandage of modernization and high knowledge. Not much different where the black body was made into a tool while the one who ruled it was white people. Combining the physicality of black people with the determination of white people is the goal of the Armitage family. This might seem to be a pessimistic conclusion. It would seem that if groups are not stereotyped on the one hand, then they will be hit with discrimination and ingroup bias on the other (McGarty : 2002).

\section{Prejudice}

Another form of racism in this narrative movie is prejudice. It is described as a negative state toward other people from different races. When we see slavery in America in the $19^{\text {th }}$ century, prejudice is often given by white people to the colored people. Prejudice is frequently motivated by the hate of white people toward colored people. They may give prejudice without any reasonable cause. Prejudice is commonly the result of generalization of the current group. The perception of every individual is often seen from the general perception toward his group. But, in this movie the researcher found the prejudice from the black people that make a negative state toward other people from different races. In this case, the different races are white people. The form of prejudice in this narrative can be seen in this following part:

In the dialogue between Rod William and Chris Washington, there is a negative view given by Rod to white people.

Chris: Okay, get your own girl.

Rod: Goddamn.

Chris: See, it doesn't matter,

Rod: 'cause you never take my advice.

Chris: Like what?

Rod: Like don't go to a white girl parents' house. She doin', licking your balls or something? 
Chris: Yeah, bye.

Rod: You know what I'm saying, Chris?

In the dialogue, Rod William as a friend of Chris on a telephone tried to remind that white people are dangerous. Don't want to be invited to a white family house. And Rod said what would they do with you? Licking your balls or something? Then Chris closes his phone and ignores his friend's advice. In the dialogue there is a negative view of black people there are Rod on white people there are Rose Armitage. The negative view of Rod William towards white people does not stop there. When Chris calls him back and says that he has been hypnotized in order to stop smoking, Rod says horrible things to Chris like the following dialog:

Rod: Bruh, how you did not scare of this, man? Look, they could've made you do all types of stupid shit. They'd have you fucking barking like a dog, flying around like you're a fucking pigeon, looking ridiculous, okay? Or... I don't know if you know this. White people love making people sex slaves and shit.

Chris: Yeah, I'm pretty sure they're not a kinky sex family, dawg.

In the dialogue, it was seen the prejudice or the negative view of a rod William towards white people. In his conversation with Chris on the telephone, it appeared that rod was so paranoid when he heard Chris had been hypnotized by his mother Rose Armitage to eliminate his addiction to cigarettes. But Rod said that it was the first step to make Chris a slave. He said that white people can do anything to Chris. They can make Chris bark like a dog, fly like a dove and the worst is they can make Chris as a sex slave because according to Rod William, white people are very happy to make other people become sex slaves.

\section{Violence}

Psychological violence is experienced by Chris Washington through some threats which are given by Missy Armitage. Threats are given to make Chris Washington under control of missy Armitage.

Missy Armitage's role in the film is particularly haunting in this system of capital as she not only forces Chris to quit smoking, but also she removes his autonomy by hypnotizing him. While audiences might initially find Rose's insistence on Chris quitting endearing in the sense that she wants him to be healthier and not waste his money on cigarettes, part of Peele's narrative strategy is that Chris was poisoning the body that would be consumed by a white host for capital and therefore this was used as the access point for Missy to psychologically imprison him. Missy's fear of bodily harm being performed against her daughter is incredibly ironic when one considers the fact that the family's motive is centered on the perpetuation of violence. Smoking becomes the guilt-induced avenue through which Missy Armitage can have Chris submit into hypnosis. It is an act that emphasizes the economic value that she places upon his body as well as her exertion of power through education and privilege.

Missy: You want to know how it works? 
Chris: You just dangle a pocket watch in front of people's faces? Is that it?

Missy: You watch a lot of tv.

Chris: When I was a kid.

Missy: Ah. Now you're feeling very sleepy. We do use focal points, sometimes to... Guide someone into a state of heightened suggestibility.

Chris: Heightened suggestibility?

Chris: That's right. That's right.

In the dialogue, Missy Armitage tries to hypnotize Chris who is actually hesitant to do so. In the scene, Missy Armitage tries to hypnotize Chris with the aim of eliminating Chris's addiction to cigarettes. But after that Missy Armitage instead asked something about Chris's mother.

Missy: Do you smoke in front of my daughter?

Chris: I'm gonna quit, I promise.

Missy: That's my kid. That is my kid.

Chris: You interested?

Missy: What about your mother? What about her?

Chris: Wait, are we...

Missy: Where were you when she died?

Chris: I don't want to think about that ... Home... Watching TV.

Missy: Do you hear the TV? What do you hear?

Chris: Rain.

Missy: Rain. It was raining.

Missy tries to get into Chris' mind by asking what Chris doesn't want to think about. There Missy Armitage has succeeded in getting into Chris' mind and really disturbing Chris's mind where he was forced to recall the incident when his mother died when he was a child.

Missy: Come here, Chris, look at me.

Chris: I found it.

Missy: Where was your mom?

Chris: She, uh... Sh-she was coming home. She wasn't home.

Missy: From work?

Chris: Mm-hmm.

Missy: Mm, and... What do you do?

Chris: Nothing.

Missy: Nothing?

Chris: I just sat there.

Missy: You didn't call anyone?

Chris: No.

Missy: Why not?

Chris: I don't know, I just... Thought that... If I did, it would make

it real. 
Missy: Hmm. You're so scared. You think it was your fault. How

do you feel now?

Chris: I can't move.

Missy: You can't move.

Chris: Why can't I move?

Missy: You're paralyzed. Just like that day when you did nothing.

You did nothing. Now... Sink into the floor.

Chris: Wait, wait, wait, wait.

Missy: Sink!. Now you're in the sunken place.

In the dialogue, Missy Armitage was seen successfully mastering Chris's mind. There it appeared after Chris told his mother suddenly his body could not move. When does Chris ask why can't he move? Missy Armitage said that Chris was paralyzed. Paralyzed like when the day his mother died, Chris just kept quiet without doing anything. Finally, Chris enters into his subconscious and is fully managed by Missy Armitage. Psychological violence itself is a type of violence in the form of pressure that can reduce mental and brain abilities. In the dialogue the violence carried out by Missy Armitage was by attacking Chris Washington. Making Chris like a guilty person who makes his mother died when he was a kid really puts tremendous pressure and suppresses his brain's ability to become weak so that it can eventually be controlled by Missy Armitage.

\section{Conclusion}

From the data analysis, the research can be concluded as follow: from the first statement of problem namely: How Racism is constructed in get out movie. There are three aspect that construct racism. First is dialogue, second is characterization and the last is plot.

From the second statement of problem namely: what Stereotype of racism that appear in get out movie. There are three form of stereotype found by researcher. First is discrimination, second is prejudice and the last is violence.

Based on the findings of the data analysis above, the result of the research can be concluded that in Get Out movie script there have many racism issue and also stereotype of racism. Not just racism from white people to black people but also racism from black people to white people.

This research is far from perfection. So the writer hopes the next research can be better than this. The writer suggest that next researcher to analyse same field in racism for different topic such as form of acceptance in race relation such as assimilation, melting pot, pluralism and multiculturalism. On different research object.

\section{References}

Abrams, M. (1979). The Mirror and the Lamp: Romantic Theory and The Critical Traition. New York: Oxford University Press.

Craig McGarty, V. Y. (2002). Stereotypes as Explanations. UK: Cambridge University Press.

D. Ary, L. J. (2010). Introduction to Research in Education. California: Wadsworth. 
D. Bordwell, K. T. (2017). Film Art ; An Introduction, eleventh edition. New York: McGraw-Hill Education.

Eagleton, T. (1996). Literary Theory An Introduction. United States: The University of Minnesota Press.

Fredrickson, G. M. (2002). Racism ; A Short Story. New Jersey: Princeton University Press.

Klarer, M. (1998). An Introduction to Literary Studies. London and New York: Routledge.

Kuntoro, R. (2005). Metode Penelitian. Jakarta: PPM. 